\title{
Acute abdomen caused by spontaneous perforation of pyometra in a patient with cervical cancer
}

\author{
Hidde M Kroon, ${ }^{1}$ Ramon GV Smolders ${ }^{2}$
}

${ }^{1}$ Department of Surgery, Erasmus MC, Rotterdam, The Netherlands

${ }^{2}$ Department of Gynaecology, Erasmus MC, Rotterdam, The Netherlands

\section{Correspondence to} Dr Hidde M Kroon, hmkroon@hotmail.com

Accepted 2 July 2016
CrossMark

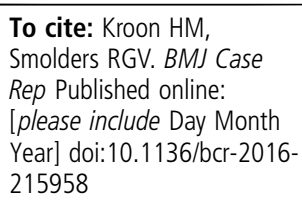

\section{DESCRIPTION}

Pyometra, the build-up of pus in the uterine cavity, is seen in $<1 \%$ of patients with cervical cancer. ${ }^{1}$ Spontaneous perforation of pyometra is rare and may cause a generalised peritonitis, mimicking gastrointestinal origin. ${ }^{2}{ }^{3}$ Despite adequate management, consisting of an emergency laparotomy, drainage of pus and sometimes a hysterectomy (reducing curative chances in case of malignancy), morbidity and mortality (>40\%) rates are high. ${ }^{3}$

A 65-year-old patient, recently diagnosed with cervical carcinoma (squamous cell; International Federation of Gynecology and Obstetrics (FIGO) stadium IIa1: Involvement of the upper two-thirds of the vagina, without parametrial invasion, $<4 \mathrm{~cm}$ in greatest dimension), was admitted to the emergency room with sudden onset of abdominal pain. Her heart rate was $120 \mathrm{bpm}$, blood pressure 85/ $45 \mathrm{~mm} \mathrm{Hg}$ and temperature was $35.2^{\circ} \mathrm{C}$. Bowel sounds were absent with diffuse peritonitis during palpation. Blood test results showed a $\mathrm{C}$ reactive protein of $267 \mathrm{mg} / \mathrm{L}$ and leucocytes of $16.2 \times 10^{9} / \mathrm{L}$. The clinical diagnosis was a gastrointestinal perforation. The CT scan, however, showed an enlarged

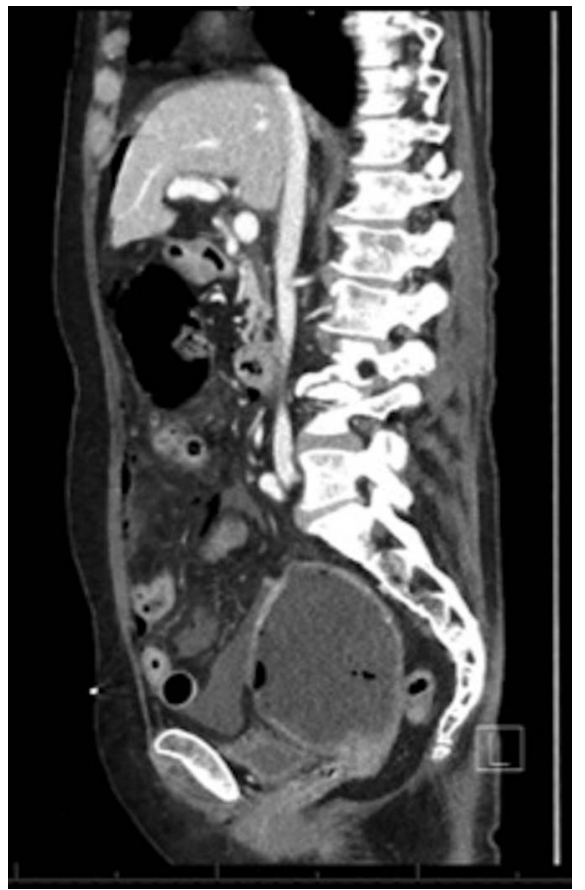

Figure 1 Sagittal view of abdominal CT scan: enlarged uterus with thickened wall. The uterus cavity was filled with fluid and air bubbles. Free air was seen in the abdominal cavity, spreading from the lower to the upper abdomen ventrally of the liver. Perforation of the uterus was not identified on the CT scan.

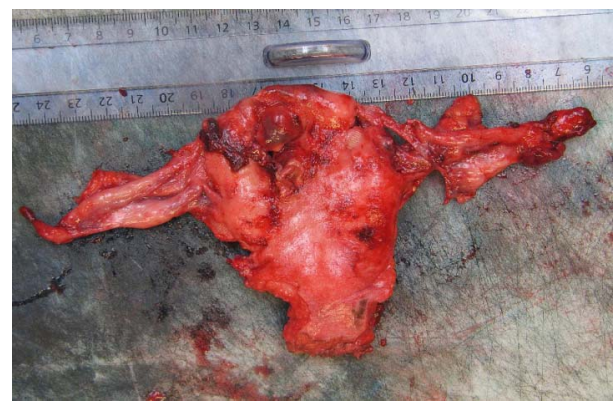

Figure 2 The resected uterus with perforation at the fundus.

uterus containing fluid and air, and free intraperitoneal air suggesting a spontaneous pyometra perforation (figure 1).

During the following emergency laparotomy, $1000 \mathrm{~mL}$ of pus was evacuated and a perforation at the fundus of the uterus was identified (figure 2). Drainage of the abdominal cavity alone did not result in sepsis control and was achieved after a radical hysterectomy.

After surgery the patient was admitted to the intensive care unit for 11 days. The postoperative course was complicated by intra-abdominal abscesses and pneumonia. She was discharged from the hospital after 46 days. Owing to the pyometra perforation the patient has not been able to complete her oncological treatment of chemoradiation.

\section{Learning points}

Spontaneous perforation of pyometra often causes a generalised peritonitis, mimicking gastrointestinal origin.

- Treatment of a patient with a spontaneous pyometra perforation consists of an emergency laparotomy with drainage of pus and hysterectomy in most cases.

- Hysterectomy following a spontaneous pyometra perforation in patients with cervical cancer, seriously compromises the planned oncological treatment.

Contributors HMK initiated writing of the manuscript, RGVS and HMK co-wrote the manuscript and contributed equally.

Competing interests None declared.

Patient consent Obtained.

Provenance and peer review Not commissioned; externally peer reviewed. 


\section{REFERENCES}

1 Vyas S, Kumar A, Prakash M, et al. Spontaneous perforation of pyometra in a cervical cancer patient: a case report and literature review. Cancer imaging 2009;9:12-14.
2 Kutuk MS, Ozgun MT, Tas M, et al. Spontaneous uterine perforation due to pyometra. J Obstet Gynaecol 2013;33:322-3.

3 Yin WB, Wei YH, Liu GW, et al. Spontaneous perforation of pyometra presenting as acute abdomen: a rare condition with considerable mortality. Am J Emerg Med 2016;34:761.e3-5.

Copyright 2016 BMJ Publishing Group. All rights reserved. For permission to reuse any of this content visit http://group.bmj.com/group/rights-licensing/permissions.

BMJ Case Report Fellows may re-use this article for personal use and teaching without any further permission.

Become a Fellow of BMJ Case Reports today and you can:

- Submit as many cases as you like

- Enjoy fast sympathetic peer review and rapid publication of accepted articles

- Access all the published articles

- Re-use any of the published material for personal use and teaching without further permission

For information on Institutional Fellowships contact consortiasales@bmjgroup.com

Visit casereports.bmj.com for more articles like this and to become a Fellow 